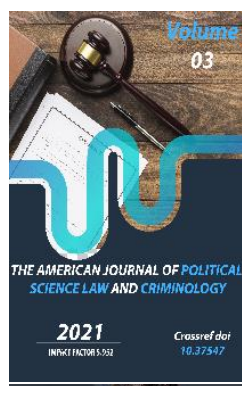

\title{
Features Of Liability For Violation Of The Rules Of Trade And Services In The Legislation Of Some Foreign Countries
}

Journal Website: http://usajournalshub.c om/index,php/tajpslc

Copyright: Original content from this work may be used under the terms of the creative commons attributes 4.0 licence.

\section{Ulugbek Akhmedov}

Tashkent State University Of Law, Theory And Practice of The Application Of Criminal Law Specialty Student, Uzbekistan

\section{ABSTRACT}

This article examines the general characteristics of criminal liability in the legislation of foreign countries for violation of the rules of trade and services.

The article analyzes the definition of offenses and criminal liability for violation of the rules of trade and services in the legislation of some foreign countries, administrative and criminal components, aggravating circumstances of violation of the rules

\section{KEYWORDS}

Offense, offense, corpus delicti, criminal liability, fine, sanction, violation of trade rules, violation of service rules.

\section{INTRODUCTION}

In determining the issues of liability for any crime, along with the social risk of the measurement, the experience of foreign countries and the conduct of external analyzes 
of habitats are of great importance. After all, on the basis of foreign experience, what is the continuation, the creative results in determining the signs of responsibility are described. Also, in the regulation of the work carried out in the Republic of Uzbekistan, as well as the implementation of the information provided, the conditions for combating the liability of any party to the administration. President of the Republic of Uzbekistan Shavkat Mirziyoyev Miromonovich on February 7, 2017

\section{THE MAIN RESULTS AND FINDINGS}

Adoption of the Action Strategy for the five priority areas of development of the Republic of Uzbekistan for 2017-2021, which defines the most important directions of state policy in the field of improving criminal and criminal procedure legislation on the basis of Decree No. PF-4947 decriminalization, plays an important role in the humanization of criminal penalties and the order of their execution. The Concept of "Improvement of Criminal and Criminal Procedure Legislation of the Republic of Uzbekistan" approved by the Resolution of the President of the Republic of Uzbekistan dated May 14, 2018 No. PP-3723 "On measures to radically improve the system of criminal and criminal procedure legislation" and ensuring the practical and reliable protection of the interests of the state "was identified as a priority to continue the policy of gradual decriminalization of certain offenses of low social risk.

In this regard, the improvement of the administrative and criminal offenses we are studying requires, first of all, in the field of public policy and on the basis of analysis of foreign experience. Given that the crime of violation of the rules of trade and services is not found in the criminal law of some foreign countries, it will be possible to develop proposals for amendments or additions to the law.

In the administrative and criminal legislation of foreign countries can be seen the peculiarities of the offense of violation of the rules of trade and services, and we will try to describe their noteworthy aspects.

First, we examine the offenses related to violations of the rules of trade and services in the legislation of the Russian Federation.

Recent amendments to the Code of Administrative Responsibility of the Russian Federation have affected the law regulating retail trade, in particular the food sector. This law was adopted in the Russian Federation on December 28, 2008 "On state regulation of trade activities." Subsequent amendments were made to the Administrative Code, which established liability for violations of the Trade Law. As a result of this reform, wholesalers and retailers in Russia were able to study the Trade Law and try to coordinate their business, but there were no specific rules defining liability for violations of the Trade Law.

The amendments create discriminatory conditions for companies engaged in the sale or supply of food products, including barriers to market entry and forcing counterparties to accept conditions prohibited by Article 13 of the Trade Law.

The maximum fine amended for violation of the law on trade is 5 million rubles and does not depend on the income of the violator from the sale of goods, in contrast to a number of violations of a pure antitrust nature. 
Thus, by adding new rules to Chapter 14 of the Administrative Code (administrative offenses in business activities), the amendments provide antitrust authorities with new means of investigating trade-related administrative offenses, controlling trade activities.

Article 144 of the Code also stipulates liability for the sale of goods, performance of work, or provision of services to the population in poor quality or in violation of sanitary regulations.

\section{In particular, it provides for the following:}

1. Sale of goods, performance of work or rendering of services:

Services that do not meet the standards and technical requirements of the population or do not comply with their models in terms of quality, completeness or packaging - lead to the imposition of administrative fines on citizens and officials.

2. Sale of goods, performance of work or rendering of services:

Providing services to the population in violation of sanitary regulations or in the absence of a certificate of conformity (declaration of conformity) confirming the safety of these goods, works or services in relation to human life and health - entails an administrative fine for citizens.

In addition, in the absence of information on producers or sellers established by citizens registered as sole proprietors in Article 145 of this Code, or trade without the use of cash registers - citizens and officials, as well as legal entities are subject to administrative fines .

Another mistake made by entrepreneurs in many countries today is to increase or decrease the prices of goods or services that are controlled by the state. According to Article 146 of the Russian Code of Administrative Offenses, these offenders are subject to administrative fines [1].

Liability for violation of the rules of trade and services is defined in the Russian Code of Administrative Liability. However, the Criminal Code of the Russian Federation does not provide for criminal liability for these offenses.

The articles of the Special Part of the Criminal Code of the Russian Federation provide a strict list of crimes, which prohibit the commission of acts specified in these articles. It is against the law to do so. Acts that are not considered a crime in the Special Part of the Criminal Code and do not provide for punishment are not considered a crime, regardless of whether they caused any consequences. In order for an act to be considered a crime, it must, of course, be specified in an article of a special part of the Criminal Code, for which a criminal penalty must be provided. If we analyze the administrative legislation of the Republic of Belarus, then the issues of liability for violation of the rules of trade and services are also legally defined.

In particular, Article 1217 of the Code of Administrative Offenses of Belarus establishes liability for violation of the rules of trade and public services. They are:

1. Violation of the rules of trade and services, fines punished with.

1. Shelf life, storage of goods, sale of expired goods - are subject to fines. This part was amended by the Law of the Republic of Belarus dated December 28, 2009 No. 98-Z.

2. In case of repeated commission within one year after the imposition of an 
administrative penalty for the same offense, provided for in the first part of this Article, a large fine shall be imposed. This norm was introduced by the Law of the Republic of Belarus dated August 7, 2003 No. 230-Z.

3. Sale of goods (works, services) prohibited by the State Control Committee of Belarus - a fine shall be imposed on an individual entrepreneur or legal entity with confiscation of property. This part of the article was amended in accordance with the Law of the Republic of Belarus dated December 28, 2009 No. 98-Z.

4. Sale or storage of goods or medicines from warehouses, bases, consumer services, trade, public catering, public utilities of public health organizations or delivery to the place of sale or concealment of goods or medicines from buyers (violation of trade rules) a fine punished with.

5. Sale of goods by hand, trays, trolleys, cars, as well as in places prohibited by law, is punishable by a warning or a fine. This norm was introduced by the Law of the Republic of Belarus dated December 28, 2009 No. 98-Z.

6. The sale of goods by a natural person who is not engaged in entrepreneurial activity in the market or in a place other than the place specified by the local executive and administrative body, shall be punishable by a fine if such person is prohibited from selling in these places in accordance with the legislation [2].

Liability for violation of the rules of trade and services is not included in the Criminal Code of the Republic of Belarus.
Another CIS country is the Republic of Ukraine, where liability for violations of trade and service regulations is stated as follows:

According to Article 155 of the Code of Administrative Responsibility of the Republic of Ukraine, violation of the rules of trade and services by employees of trade, catering and services, citizens engaged in entrepreneurial activities is punishable by a fine.

Sale of goods from warehouses, bases, auxiliary rooms and consumer cooperatives of state trade (catering, service) enterprises in violation of the established rules, as well as employees and officials of state trade (catering and service) enterprises (organizations) concealment from buyers of goods committed by a non-consumer cooperative will result in a fine in the amount of the minimum base calculation.

Also, Article 1551 of this law establishes liability for violation of the procedure established by law for settlements in the field of trade, catering and services.

This situation results in a heavier penalty if committed by a person who has been held administratively liable for the same offenses for a period of one year.

In addition, Article 1552 of this Code deceives the buyer or customer, ie in the sale of goods, works, services, employees of trade, catering and services - citizens by business entities in excess of the established prices and tariffs or other frauds. measurement, collection, calculation will result in liability with a fine [3].

The Criminal Code of the Republic of Ukraine also does not address the issue of liability for violation of the rules of trade and services. 
Let us now turn to the state of Latvia, which is located in the north-west of Europe, on the shores of the Baltic Sea, and today has a developed economy.

According to Article 155 of the Code of Administrative Offenses of the Republic of Latvia, violation of the rules of trade, catering or services is punishable by a fine of seven to two hundred and ten euros for individuals and fifteen to seven hundred euros for legal entities. If the same actions are committed repeatedly within a year after the imposition of an administrative penalty - individuals will be fined from two hundred ten to three hundred and fifty euros, and legal entities from seven hundred to one thousand four hundred euros.

Failure to comply with the procedure established by Article 1552 of this Law for the accounting (accounting) of income and expenses at the cash desk - entails a fine of one hundred and forty euros to two hundred and ten euros.

Also, according to Article 1554, trading in illegal places - leads to the confiscation of goods in illegal places of trade.

\section{CONCLUSION}

Similar actions committed by a person convicted two or more times for trading in an unauthorized place during the year are punishable by a fine of up to two hundred and ten euros or administrative detention for three to fifteen days with confiscation of goods.

In addition, according to Article 1555 of this law, non-compliance with the expiration date of the product, ie sale after expiration, sale or distribution of goods not specified in the regulatory decisions - a fine of seven to three hundred and fifty euros for individuals and fifteen to seven hundred euros for legal entities. causes.

In addition, trading in petroleum products in places not permitted by the administrative legislation of the Republic of Latvia, in particular Article 1556, entails confiscation of petroleum products in trade outlets and a fine of one hundred and forty to seven hundred euros[4].

Among the signs of the objective side of a particular crime are the essential typical signs of the external side of this type of crime in their generalized expression, distinguished from the countless possible manifestations of the corresponding type of crimes committed in reality [5].

We are convinced that the administrative and criminal legislation of the Republic of Uzbekistan, in comparison with the administrative and criminal legislation of foreign countries, the legislation of the Republic of Uzbekistan is liberalized in accordance with the criteria of social justice.

\section{REFERENCES}

1. Code of administrative offences of the Russian Federation no. 195-fz of december 30, 2001, april 29, 2008.

2. Code of the Republic of Belarus on administrative law (National Register of Legal Acts of the Republic of Belarus, 2007, № 6, 2/1298) <H10700201>

3. Code of Ukraine on administrative law from December 7, 1984 № 8073-X (with changes and additions to the state on 17.03.2020).

4. Criminal Code of the Republic of Latvia: Law, adopted by the Sejm on June 17, 1998 
and approved by the President of the State on July 8, 1998 (with changes, introduced on May 18, 2000) «LV», 08.07.98, № 199/200

5. Khudaykulov F. K. Signs Of The Objective Side Of Crime In The Theory Of Criminal Law Belonging To The Romano-Germanic Legal Family: Theoretical And Practical Problems //The American Journal of Political Science Law and Criminology. 2021. - T. 3. - №. 01. - C. 57-62.

6. Allanova A. Leaving and entering illegally the Republic of Uzbekistan (instructions and specific features) //Review of law sciences. - 2018. - T. 2. - №. 2. - C. 29.

7. Хожиев Н. К. ЖАЗОНИ ИЖРО ЭТИШ МУДДАТИ ЎТИБ КЕТГАНЛИГИ МУНОСАБАТИ БИЛАН ЖАЗОДАН ОЗОД ҚИЛИШНИНГ ШАРТЛАРИ ВА ХОРИЖ ТАЖРИБАСИ //Jurisprudence. - 2020. - Т. 1. - №. 1.

8. Курбанов М. М. ТАДБИРКОРлИК ФАОЛИЯТИГА ТЎСҚИНЛИК ҚИЛИШ, ҚОНУНГА ХИЛОФ РАВИШДА АРАЛАШИШ БИЛАН БОҒЛИҚ ЖИНОЯТЛАР УЧУН ЖАВОБГАРЛИК БЕЛГИЛАНИШИНИНГ ИЖТИМОИЙ ЗАРУРАТИ //«Хуқуқий тадқиқотлар» электрон журнали. - 2020. - Т. 2. - №. SPECIAL 3.

9. Шамсидинов 3. 3. НОҚОНУНИЙ МОЛИЯВИЙ ОПЕРАЦИЯЛАР БИЛАН БОҒЛИҚ АЙРИМ ҚИЛМИШЛАРНИ КВАЛИФИКАЦИЯ ҚИЛИШ МАСАЛАЛАРИ //«Хуқуқий тадқиқотлар» электрон журнали. - 2020. - Т. 2. - №. SPECIAL 3.

10. Allanova A. Aggravating circumstances of illegal travel abroad or illegal entry into the Republic of Uzbekistan //Review of law sciences. - 2020. - T. 4. - №. 1. - C. 3. 